\title{
Forgiveness: A Christocentric perspective
}

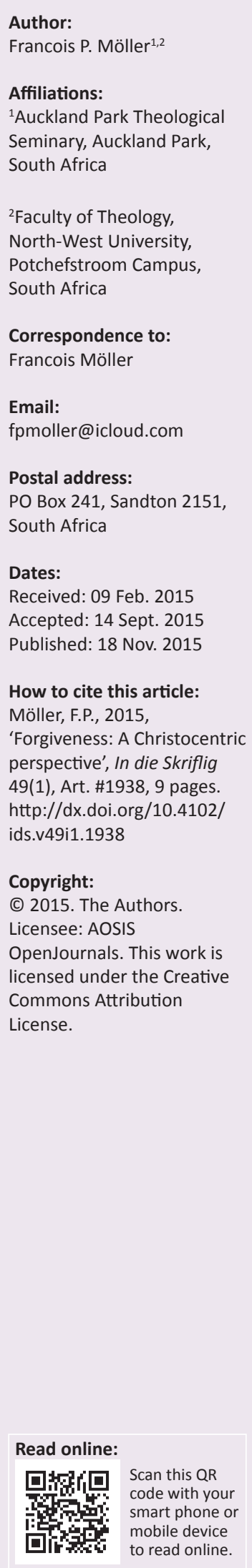

Forgiveness is at the core of Christianity and is a gift of God in conquering sin and its destructive fruits. It is therefore important to understand the biblical principles and norms in this regard. This will be done from a dogmatic-ethical view that will be motivated by a Christocentric perspective. Central to forgiveness is what God has done in Christ to move towards us in brokenness and sin whilst inviting our repentant response. Christ has done a complete work in this regard, and therefore God is faithful and righteous to Christ to forgive us our sins and purify us from all unrighteousness. A Christocentric view accentuates God's initiative in forgiveness and necessitates us to differentiate between God's unconditional offering of forgiveness and his conditional applying of forgiveness. It is shown that this differentiation is crucial in the understanding and application of forgiveness as portrayed in the Bible. Christ is normative in offering forgiveness, and therefore it should be done in his name. Christ is also normative in the realisation of forgiveness and therefore he is the Subject of forgiveness, not a human being. In conclusion the problem of offered forgiveness that does not evoke repentance and confession is dealt with.

Vergifnis: ' $\mathbf{n}$ Christosentriese perspektief. Vergifnis is wesenlik deel van die Christendom en ' $n$ gawe van God in die oorwinning van sonde en sy vernietigende gevolge. Dit is daarom belangrik om die bybelse beginsels en norme in hierdie verband te begryp. Dit sal gedoen word vanuit 'n dogmaties-etiese benadering gemotiveer deur ' $n$ Christosentriese perspektief. Dit wat God in Christus gedoen het deur na ons uit te reik in ons gebrokenheid en sonde in afwagting op ons berouvolle reaksie, staan in die kern van vergifnis. Christus het in hierdie verband 'n volkome werk gedoen, en daarom is God getrou en regverdig teenoor Christus om ons sondes te vergewe en ons van alle ongeregtigheid te reinig. ' $n$ Christosentriese perspektief aksentueer God se inisiatief in vergifnis en noop ons om tussen die onvoorwaardelike aanbieding van vergifnis en die voorwaardelike realisering daarvan te onderskei. Daar word aangetoon dat hierdie onderskeid essensieel is vir die verstaan en toepassing van vergifnis soos dit in die Bybel voorgehou word. Christus is normatief in die aanbieding van vergifnis, en daarom moet dit in sy Naam geskied. Christus is ook normatief in die realisering van vergifnis, en daarom is Hy die Subjek van vergifnis, nie die mens nie. Ten slotte word die problem van aangebode vergifnis behandel, wat nie berou en belydenis tot gevolg het nie.

\section{Introduction}

The act of forgiveness is one of the most powerful occurrences conquering the reality of sin and its destructive fruits as manifested in the broken relationships with God and man. No wonder there is a strong biblical emphasis on forgiveness as an act of God, but also an expected deed from man. In practical theology forgiveness plays an important role (especially in counselling), but a dogmatic-ethical view on forgiveness should be regarded as fundamental. It is crucial to understand the biblical principles and norms concerning forgiveness before applying them in our relationship with God and fellow human beings. Macaskill (2005:1) points out that the lack of any consensual definition of forgiveness is a serious weakness in research literature as forgiveness is at the core of Christianity. This study is therefore an attempt to comprehend a biblical understanding of forgiveness from a dogmatic-ethical approach. This approach will be motivated by a Christocentric perspective. Christ is the truth (Jn 14:6), and true understanding of forgiveness relates to what he has done for us in this regard.

Vos (1988:31), in reference to the parable of the prodigal son, remarks: 'Hierdie liefde, vergifnis en aanvaarding kan nie verdien word nie. Dit kan maar net ontvang word' [This love, forgiveness and acceptance cannot be deserved. It can only be received]. Because it is not deserved but imbedded in unconditional love, forgiveness is a free gift of God to man and man to man. Augsburger (1995) states: 
The restoring of an attitude of love is a prerequisite to the forgiveness process. It is not in itself forgiveness, though love is a forgiving attitude which reaches towards restoration. Wrongdoing is not a valid reason for not loving another. Enemylove is the nature of God and of God's children, and thus a willingness to forgive and to work at the forgiveness process until reconciliation is possible. (p. 389)

The biblical message is that God both forgives and loves; and man is enjoined both to forgive and to love.

\section{Central to forgiveness}

As central to forgiveness, Lehmann (1975:131) identifies an act of 'sending away'. God 'sends away' what man has done in violation and disavowal of his will, and receives man back into uninhibited fellowship. Also man's forgiveness to one another is seen as an act of 'sending away' what has come between him and his neighbour. To 'send away' is indeed an important aspect of forgiveness, and relates to the Greek verb áфićval [to send away; to forgive] as mainly used in the Gospels. Paul uses the verb $\chi \alpha \rho 1 \xi o \mu \alpha 1$ to express the idea of forgiveness (2 Cor 2:7, 10; 12:13) emphasising that forgiveness is a gift from God. This word is used for God's forgiveness in Christ for humanity (Col 2:13) and of both human and divine forgiveness in Colossians 3:13 and Ephesians 4:32. Sometimes this verb is also used to refer to the cancellation of a money debt (e.g. Lk 7:42) and etymologically includes the idea of grace (Bash 2007:98). However, that which is central to forgiveness cannot in the first instance be determined by semantics, but rather what God has done in Christ to move towards mankind in their brokenness and sin whilst inviting their repentant response.

The centrality of Christ in this regard is also emphasised by Bonhoeffer (1964):

Our concern is with the real man, sentenced and made new. The real, sentenced and renewed man exists nowhere else save in the form of Jesus Christ and, therefore, in the likeness of this form, in conformation with him. Only the man who is taken up in Christ is the real man. Only the man who suffers the cross of Christ is the man under sentence. Only the man who shares in the resurrection of Christ is the man who is made new. Since God became man in Christ all thought about man without Christ has been a barren abstraction. (p. 110)

\section{God's faithfulness and righteousness to Christ}

God's faithfulness and righteousness to forgive a sinner his sins and to cleanse him from all unrighteousness (1 Jn 1:9) could not be isolated from what Christ has done in this regard. Forgiveness is not a mere 'sending away' or a cheap cover-up of sin, like an artist covers up a mistake with his brush. It is all about God's faithfulness to Christ for what he has done for humanity on the cross, and his righteousness because the price of $\sin$ has been paid for. In fact, if man truly repents of sin, and God does not forgive him, he would have been unfaithful and unrighteous to that what Christ has done in this regard. Paul says in Colossians 1:13-14 (NIV): 'For He has rescued us from the dominion of darkness and brought us into the kingdom of the Son He loves, in whom we have redemption, the forgiveness of sin.' Any refutation of the centrality of Christ in understanding forgiveness, both as an act of God and of man, will lead to a misconception of what forgiveness is all about.

\section{Forgiveness is completed in Christ}

God is satisfied with that what Christ has done on man's behalf. The death of Christ has paid for all sins - it was sufficient. Christ's completed work in this regard should not be underestimated, and as God is satisfied, man should also be satisfied what Christ has done for him. Duffield and Van Cleave (1983:222) write in this regard:

One of the great problems in society today has to do with the rehabilitation of those who have served time for a crime committed. Even though he has met his debt to society, it is difficult for such a person to find his place in the community again. He has the mark of a criminal against him ... this is why a large portion of those who have been incarcerated drift back into the company of the criminal element and very often are arrested and sentenced to another period in prison. Thank God that His grace is so abundant that we are received into His favor as though we had never broken His laws. (p. 222)

This restoration of favour is especially illustrated in the parable of the prodigal son. The son was treated different than a discharged criminal - through forgiveness he was treated as though he never sinned (Lk 15:11-32). Barth (1966) reminds us that forgiveness exists in Christ:

And as for those who have to complain about me, the devil and his cohorts, why, He is sitting in my place. That is my situation. Thus I am acquitted and may be wholly joyful, because the accusations cease to come home to me. The righteousness of Jesus Christ is now my righteousness. That is the forgiveness of sin. (p. 152)

\section{God takes the initiative in forgiveness}

Fiddes (2010) affirms God's initiative in this regard:

The Gospel stories of Jesus seem to show his taking an initiative which is characteristic of forgiveness, offering acceptance even before there is a sign of sorrow in the offender, in the hope that repentance will be evoked. (p. 191)

This is emphasised by Paul in Romans 5:8 by saying Christ has died for us whilst we were still sinners, and alerts us to the fact that in the suffering of the Forgiver on the cross, it was God who took the responsibility for man's offences against him by sharing in the human suffering that results from these offences. The aim of forgiveness is reconciliation, and the cross as an event of reconciliation and as a theodicy focuses both on the suffering of God and of humankind. Nowhere has God penetrated more deeply into the darkness of sin and absorbing its effects as in forgiveness.

God's initiative in forgiveness is therefore inseparable from a love that enters in Christ our sorrowful and painful situation caused by our rebellion against him. Forgiveness is never 
'cheap grace', but an explicit theodicy that reveals a love for the offender to the extremity of the cross. Only a suffering participation from Christ could meet the demand of Romans 6:23 as Paul assures: 'For the wages of sin are death, but the gift of God is eternal life in Christ Jesus our Lord' (NIV).

\section{God's unconditional willingness to offer forgiveness}

Because the wages of sin is met, Christ's suffering causes forgiveness to be a creative act of reconciliation. This suffering was done by God through Christ without any merit or action from mankind. God's willingness to offer forgiveness is therefore unconditional. It was done regardless whether man believes it or not. It became an objective and historical fact initiated by God when Christ died on the cross.

The initiative of God in offering forgiveness is always accompanied by the anticipation that repentance will be provoked. Repentance is important because of the difference between God's willingness to offer forgiveness and God's application of forgiveness (absolution of sin). Without this differentiation the confusion between unconditional and conditional forgiveness is elicited. The unconditional act of God's willingness to offer forgiveness in Christ as expressed in his love for mankind is realised by God's conditional application of forgiveness in the offender's life. The denial of this assertion inevitably leads to a soteriology of universalism (Talbott 2008:446-461). In contrast to Bash (2007:96) who does not distinguish between repentant and unrepentant wrongdoers in the act of forgiveness, as well as Tournier (1974:192) who claims that if love is unconditional, then forgiveness should also be unconditional, Augsburger (1995:389) rightfully declares: 'God's gracious love is unconditional, but the consequent forgiveness is conditional. It requires the repentant response which receives love, reappropriates relationship, and experiences reconciliation.' This is also underscored by Geisler (2010):

God understands our weaknesses and forgives our sins upon our confession. He knew that we would not always be able to keep his commandments. And while God never lowers his demands to our level, he does provide forgiveness for us. (p. 312)

The sinner's repentant response to receive forgiveness was also something prominent in the early church. Latourette (1953:216), for example affirms that already in the 2nd century baptism was regarded by a large part of the church as washing away all offences committed before it. He continues by declaring that the problem to deal with was the question of what happens with those sins committed after baptism. He points to the answers given by several church fathers. Tertullian (AD 160-225) mentioned seven serious or 'deadly' sins a believer cannot easily be forgiven for - idolatry, blasphemy, murder, adultery, fornication, false-witness and fraud. The 'Shepherd of Hermas' allowed the possibility of one repentance after baptism, and that was concurred by Clement of Alexandria (AD 150-215). Clement said that if the church allows a continual and successive repentings for sin, Christians would differ nothing from those who never have been Christians. Later the first Council of Nicea (AD 325) declared that:

None who was penitent was to be forbidden the communion on his death bed, but others might be kept waiting for from two to ten years. For them, as for other penitents for grave offenses, there were grades through which they passed before readmission to full communion. (Latourette 1953:216-217)

Macquarrie (1992:135) confirms that the bishop was initially the agent of reconciliation, and that there was some public act of penance, though it was always clear that this did not earn forgiveness but was rather a token and manifestation of the change of heart. Later confession became a private matter between the penitent and his priest, and penances likewise were privatised and reduced to reciting Scripture. As far as the Roman Catholic sacrament of penance is concerned, Macquarrie states that it was valued even outside the Catholic Church:

Luther indeed continued to value it, though with some ambivalence, but it is interesting to note that some Lutherans have continued to attach importance to a sacramental form of confession and absolution, especially Dietrich Bonhoeffer, who testifies of the value of the practice in the underground seminary which he operated in Germany at the time of the Hitler regime. (1992:135-136)

It seems that unconditional forgiveness of sin by a bishop, priest or any believer was unknown to the Early Church up to at least the Reformation (Foster 1995:96-97).

\section{God's conditional applying of forgiveness}

Two conditions are mentioned in the Bible regarding the application of God's forgiveness in Christ. First of all, confession and repentance, and secondly, forgiving one another (Mt 6:14; Mk 11:26; 1 Jn 1:9). These two conditions are, however, not an indication that in the application of forgiveness the initiative has shifted from God to man. Both these conditions are fruits of the work of the Holy Spirit (Jn 16:8) rooted in God's unconditional willingness to offer forgiveness. Richardson (1976) accentuated this truth in the doctrine of forgiveness:

The doctrine should be safeguarded from any idea that repentance is the human contribution to the bargain. We are not talking of a new kind of fellowship consequent upon human action, or the kind of treaties between nations, but of a new kind of fellowship created by God, individually, personally and decisively, unmerited and undeserved. (p. 130)

It is expected that God's conviction and move towards man in his sin and brokenness will firstly cause confession and repentance, and secondly a willingness to forgive one another. If this expectation is not met and the exact opposite is revealed, a manifestation of $\sin$ is disclosed. Why sin often prevails in this regard is not clear. It runs counter all understanding and can in fact not be detached from the mystery regarding the origin of sin. Paul refers to the Galatians as being foolish and bewitched in their sinful response to the 
gospel (Gl 3:1). This prevalence of sin is difficult, actually impossible to understand - it is an irrational event.

\section{Confession and repentance}

The connection between confession and repentance on one hand and forgiveness of sin on the other is Scriptural (Job 42:6; Jr 8:6; 31:19; Mt 21:29, 32; Lk 17:3-4; 1 Jn 1:9). Collins (1995:147) states: 'When we yield to temptation, he freely forgives those who confess, genuinely repent, and determine to go their way and sin no more.' Sin that is not followed by confession and repentance stands against the offender. In Psalm 32 David writes about his sin: 'When I kept silent, my bones wasted away through my groaning all day.' In other words, without confession, he suffered inwardly - but he continued in verse 3-5: 'Then I acknowledged my sin to you and did not cover up my iniquity. I said: "I will confess my transgressions to the Lord" - and you forgave the guilt of my sin' (NIV). The message of this Psalm is captured in the words of Proverbs 28:13 (NIV): 'He who conceals his sin does not prosper, but whoever confesses and renounces them finds mercy.' Crabb (1991:115) declares that: ' $[w]$ hen $\sin$ is realized and the gospel embraced, then forgiveness is celebrated.' In the New Testament message it becomes clear that man's repentance of sin is actually remorse of what was done to Christ as the One who has died for all man's sin (Rm 6:10; 2Cor 5:15).

This remorse of what was done to Christ is accentuated by Brillenburg Wurth (1957) and in terms of 2 Corinthians 7:10 he (1957:179) said: 'Een derglijke droefheid naar God werkt hier werkelijk een onberouwelijke bekering tot zaligheid' [Such sorrow towards God works here in reality a conversion to salvation that will leave no regret]. In proceeding his argument of the necessity of remorse to God he quoted Kraan who says:

Het is wel vreselijk dat wij het leven niet meer kunnen vinden dan langs de donkere smartenweg van deze droefheid. Maar het is anderzijds toch heerlijk, dat deze weg des leven er voor ons noch is. Want uit het zaad van deze droefheid rijpt de vrucht der waarachtige levens-vreugde. Uit deze tranen wordt de lacht geboren. Uit deze dood rijst het nieuwe en eeuwige leven. [For sure it is alarming that we could not really find life but on the dark remorseful road of this sorrow. But otherwise it is still glorious that this way of life is yet there for us. For out of the seed of this sorrow the fruit is ripened for true joyful life. Out of these tears laughter is born. Out of this death new and eternal life is risen.] (Brillenburg Wurth 1957:180, [author's own translation])

Confession and remorse are important in God's act of forgiveness. It is only sin that was done in ignorance and not brought to the light that is forgiven without confession. The distinction between sin in ignorance and in defiance is already made in Numbers 15:27-31. As soon as sin in ignorance was, however, brought to the attention of the sinner, then he had to make a guilt offering to be forgiven ( $\operatorname{Lv} 5: 17-19)$. Something similar is found in Paul's remark to Timothy: 'Even thou I was once a blasphemer and a persecutor and a violent man, I was shown mercy because I acted in ignorance and unbelief' (1 Tm 1:13; NIV). However, when his sin was realised, he regarded himself as the worst amongst sinners
(1 Tm 1:15). When realising one's sin, it stands to reason that confession and remorse should follow, but without realising it, confession and remorse is not possible. Paul taught that through the law of God we become conscious of sin (Rm 3:20), but apart from the law, sin is dead ( $\operatorname{Rm} 7: 8)$. Christ's bestowal of forgiveness on the cross whilst no confession was made, should also be understood in terms of this truth as underscored by his words: 'for they do not know what they are doing' (Lk 23:34; NIV).

\section{We have to forgive one another}

Bash (2007) refers to forgiveness as a gift of God at the eschaton when the kingdom of God is consummated and continues:

Until the kingdom will be established, forgiveness is to be practiced and its future forms demonstrated in the present among Jesus' disciples. In other words, forgiveness is an ideal of human conduct modeled on the eschatological forgiveness of God. (p. 90)

The second coming of Christ is indeed the completion of reconciliation between God and man and between man and man, but this reconciliation is impossible without the act of forgiveness demonstrated in the now. The Lord expects us to forgive one another as he has forgiven us. Romans 3:23 teaches that all have sinned and lack the glory of God. We need forgiveness because we have sinned against God, ourselves and others. The one who has received forgiveness, has to give forgiveness as well. The one who is not willing to do that, will find that this unforgiving attitude results into bitterness, resentment and hatred. These are all things that violate the image of God in man. An unwillingness to forgive becomes a serious stumbling block for God's recreative work in a person's life. It is because God loves mankind that he urges them to forgive others and be delivered from emotions that harm them inwardly.

Christ has set the example in this regard, and therefore God feels strong about this second condition: 'If you forgive men when they sin against you, your heavenly Father will also forgive you. But if you do not forgive men their sins, your Father will not forgive your sins' (Mt 6:14-15; NIV). In Our heavenly Father prayer it seems that this principle is presupposed: 'Forgive us our debts, as we also have forgiven our debtors' (Mt 6:12; NIV).

Thus, God's forgiveness to man is preceded with man's forgiveness bestowed to others. To forgive someone is not always that easy; especially if that person has caused great harm or intensively hurt a person's feelings. Nevertheless, it is impossible to forgive someone in depth if one has not received forgiveness himself. One can only give what he has received, and if he has not received forgiveness, he cannot truly offer forgiveness to someone else. To forgive someone as God forgives in Christ means that one has to be first touched by God in this regard and has experienced through the work of the Holy Spirit forgiveness of one's sins. This is the only way in which God's attitude may become your own 
attitude, and an important principle in counseling people who find it difficult to forgive.

Forgiveness is not an act whereby a person merely forgot what the other person has done to him. Meiring (2009) in reference to the violence people suffered in South Africa, correctly remarks:

Hoe kan jy vergeet wat met jou man en seun in die oprit by jou huis gebeur het? Hoe kan 'n vrou vergeet dat sy verkrag is? Hoe kan ' $n$ hele gemeenskap die lyding van die verlede vergeet? Een ding is duidelik: Vergifnis en versoening kan nie op amnesie (geheueverlies) gebou word nie. [How can you forget what happened to your husband and son on the driveway of your home? How can a woman forget how she was raped? How can a whole society forget the pain of the past? One thing is clear: Forgiveness and reconciliation cannot be built upon amnesia.] (p. 163, [author's own translation])

Even God will not forget someone's sins, but if one is forgiven, he will not hold it against such a person. Christian ethics therefore demands that the offering of forgiveness involves a decision never to use or hold that which the offender has done against him again. To keep persistently to this decision (sometimes forgiveness is a process of try and fail), will result into a situation where one actually forgot the sins committed to oneself: 'The attempt to force people to forget what cannot be forgotten only puts them in bondage and confuses the meaning of forgiveness' (Foster 1995:97).

When one truly forgives a person as God forgives, something of the grace and love of God is demonstrated in a very special way. It does not only have a healing effect on the forgiver, but also on those forgiven! In this manner one becomes a co-worker of God in your recreative act in others' lives as well as in your own. This creative act includes the forgiver's identification with Christ's suffering for your sins against him. Fiddes (2010:191) remarks in this regard: 'The process of forgiveness alerts us to the fact that the suffering of the forgiver has a creative effect. Only a suffering participation can alter the situation.'

The more persons reveal the disposition and attitude of Christ, the more they become healthy and joyous persons. Wright (2009:308-312) repeatedly emphasised that many of our sicknesses (not only mentally but also physically) can be derived from a disposition of unforgiveness. A willingness to forgive should be offered regardless of one's own feelings - it is a command from the Lord, not a feeling or suggestion. Vorster (2004) underscores this truth:

Acceptance of guilt and true remorse should be answered with a willingness to forgive. As in the case with the concept of truth, forgiveness in a Christian ethical sense is a deeply religious concept which is founded in Christology. (p. 277)

Man's relationship with God is not built upon feelings, but on obedience to him. Being obedient, one will discover that emotions and acts will adjust.

\section{Christ is normative in forgiveness}

In the fourth chapter of Paul's letter to the Ephesians, he emphasises the unity of the body of Christ and how it should be endorsed amongst believers. In verse 32 he writes: 'Be kind and compassionate to one another, forgiving each other, just as in Christ God forgave you' (NIV). Here forgiveness should be offered as $\kappa \alpha \theta \omega \varsigma$ [just as, or in the manner that] God forgave us. God did it in Christ as a reality in the past

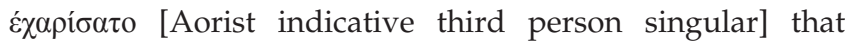
ought to be demonstrated by believers in their present relationships. The past tense underscores the mentioned theological principle that God takes the initiative in this regard. This principle is also reflected in Colossians 3:13

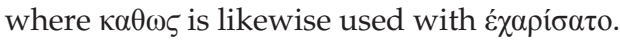

\section{Offering forgiveness like Christ}

In a Christocentric view on forgiveness the believer should likewise take the initiative by a willingness to offer forgiveness and acceptance even before the offender shows any sign of sorrow. This is also accentuated by Ridderbos (1969):

On the basis of the blessing given in the remission of sins, God demands from the man thus blessed with this grace his readiness also to forgive. Moreover this willingness is also represented as the fruit of the grace of God that has been given him. (p. 249)

This is the way the forgiver is actually discovering how to become one with Christ's willingness to suffer for our transgressions against him. The courage of the believer's willingness to accept the offender is entrenched in the knowledge of self being accepted by Christ. In the context of forgiveness and a willingness to accept the offender, Küng (1986) writes:

Acceptance is absolute, without inquiry into the past, without special conditions, so that the person liberated can live again, can accept himself - which is the most difficult thing, not only for the tax collector. This is grace: a new chance in life. (p. 279)

Forgiveness in this sense is to move towards the sinfulness and brokenness of the offender not as a harsh critic, but as someone who has been drawn alongside the offender in own sinfulness and brokenness, remembering that Christ has taken the sin and brokenness of both the forgiver and the offender upon Him. This acceptance and willingness to offer forgiveness is, however, always accompanied with the hope that confession and repentance from the side of the offender will be evoked.

As it is in our relationship with Christ, the believer's willingness to offer forgiveness is unconditional, but the actual granting of forgiveness (absolution) is conditional. This assumption may dissolve the paradox between Matthew 18:21-22 and Mark 11:25 where forgiveness seems to be unconditional, and Matthew 18:15-16 as well as Luke 17:3-4 where forgiveness is conditional. The assumption is that the former reference has to do with the willingness to 
offer forgiveness, whilst the latter reference has to do with the actual granting of forgiveness.

\section{Forgiveness in the Name of Christ}

Both the willingness to offer forgiveness and the actual giving thereof is accomplished in the Name of Christ. This implies to acknowledge what Christ has done in this regard in offering and applying forgiveness. The believer may offer forgiveness only because Christ has died for the transgressions of the offender, and the offender receives forgiveness only after confession and repentance. MacNutt (1979:152) states: 'No one doubts that Jesus died for our sins and took them away, provided we do our part and repent. This is salvation and healing at the deepest level.' In other words, forgiveness that was offered for man as an objective truth should be subjectively accepted as revealed in repentance. The actual forgiveness of sin is, however, performed by God alone and is therefore granted in his Name. No human being has the power to absolve sins.

This principle also lived in the hearts of the Scribes and Pharisees. After a paralysed man was lowered through the roof for healing, it is said:

When Jesus saw their faith, He said to the paralytic, 'Son your sins are forgiven'. Now some teachers of the law were sitting there thinking to themselves: 'Why does this fellow talk like that? He's blaspheming! Who can forgive sins but God?' (Mk $2: 5-7 ; \mathrm{NIV})$

The reason why some teachers of the law reasoned like that was because this same principle was found in the Old Testament. The forgiveness of man's sin was accompanied with a sacrifice and a confession like: 'God I have sinned against thee and deserve death. I am sacrificing this animal to you asking that the penalty of my sin will be upon this animal and therefore forgive me.' Sacrifices were never brought to a human being for forgiveness, because only God could forgive sins. Even the Roman Catholic sacrament of penance on the basis of John 20:23 is done in the Name of Christ. Macquarrie (1992) declares:

Though the priest may use the words 'I absolve you', the language makes it quite clear that he does it only in the Name of God and by the commandment given to him to announce the forgiveness of sins. (p. 139)

This is also confirmed by the Roman Catholic theologian Cantalamessa (2003:126): 'The church only carries out a ministry; it is the Holy Spirit that transforms the sinner and makes the sinner justified.' In this way the forgiveness of sin is seen by Duffield and Van Cleave (1983:96-97) as one of the divine attributes of Christ.

Brunner (1964:292-295) does not hold such a Christ-centred view on forgiveness. He differentiates between three forms of forgiveness in the Bible - through the sacrificial death of an animal; through the prophetic word of revelation (spoken by some prophets and Jesus); and through Christ's death on the cross. He (1964) says:
It was Paul who first connected the two elements, the death of Jesus and the forgiveness of sins; in so doing the purely spiritual prophetic religion of the genuine Gospel of Jesus was saddled with priestly sacrificial ideas from the Old Testament, and thus its meaning was obscured. (p. 292)

The death of Christ is not for him the foundation of God's forgiveness, but rather God's authority. Brunner (1964) declares:

Whether this message (of forgiveness) from 'beyond' comes through the Prophetic Word of revelation, or the authoritative Messianic Word of Jesus, or through His death on the Cross, is primarily less important than the other fact: that in each case it is something which must happen in a region beyond and outside of all human effort. In any case, forgiveness can never be taken for granted; it is something incomparable, which can only be granted on God's authority. (p. 294)

The Old Testament sacrifices for committed sins were, however, not religious acts standing on their own authority, but were foreshadows of what Christ would have done on the cross (Helberg 1983:103). The blood of a sacrificial animal could as such not take away a person's sins (Heb 10:4). Only God could do that, and he has done it on Golgotha. This is also applicable to prophetic words of forgiveness. In terms of the prophets and forgiveness Eichrodt (1967) claims that:

... the removal of guilt by forgiveness is understood as entirely a matter of God's personal dealing with man. ... If it is in the thought of the prophets that this can most obviously be seen to be true, the reason is that with them forgiveness is increasingly viewed in an eschatological perspective. (p. 457)

This eschatological perspective was closely linked to what the coming Messiah would have done for them in terms of the removal of sin.

In the New Testament it is clear that forgiveness in the deepest sense of the word could only take place on the basis of Christ who would have died for the sins of the world. John 1:29 says: 'The next day John saw Jesus coming towards him and said: "Look, the Lamb of God, who takes away the sin of the world!"' In other words, Brunner is not correct by assuming that Paul was the first one to connect the death of Christ with the forgiveness of sin. Here it is done by John the Baptist calling Christ the Lamb of God. If forgiveness of sin could have been accomplished by other means but the blood of Christ, then the question could be asked: Why did Christ died for our sins? Then his death was superfluous and the forgiveness of sin, as suggested by Brunner, could then be realised only by virtue of God's authoritative word!

The forgiveness of sin finds its fulfillment and actual meaning in the death of Christ on the cross. This means that forgiveness offered to another person can only be done on account of what Christ has done in this regard. Man may offer forgiveness because Christ has died for the sin that was done to him. If Christ had not died for man's sins, forgiveness is not a possibility. 'Without the shedding of blood there is 
no forgiveness' (Heb 9:22; NIV ; cf. also Lv 17:11). God will never overlook sin - the penalty of sin is death ( $\mathrm{Rm}$ 6:23). Believers are only instrumental in the hands of God to offer forgiveness, but it is essentially God that forgives and absolve sin through Christ, not believers themselves.

Consequently, believers offer offenders forgiveness in the Name of Christ, not in their own names. After Jesus' resurrection he told his disciples: 'This is what is written: The Christ will suffer and rise from the dead on the third day, and forgiveness of sins will be preached in his name to all nations' (Lk 24:46-47, NIV). In fact, not only forgiveness, but every Christian action should be done in the Name of Christ: 'And whatever you do, whether in word or deed, do it all in the name of the Lord Jesus, giving thanks through God the Father through him' (Col 3:17; NIV). Offering forgiveness to another person is actually a prayer to God to realise forgiveness in the offender's life on strength of Christ's death for your own sins, but this prayer will remain unanswered unless true repentance is evoked.

\section{The realisation of forgiveness in Christ}

Because God is the Subject of forgiveness, it implies that he alone determines whether man's offering of forgiveness will also lead to the actual absolution of the offender. The offering of forgiveness is only effective when the offender accept it with confession and remorse. God who is able to look into the heart of a person knows whether confession and remorse are sincere or not. The very fact that forgiveness was bestowed to offenders does not automatically mean that they are absolved from that sin. It remains God's prerogative to answer such a prayer as it suits him.

Forgiveness is initiated by God not only because Christ has paid for man's sins, but also because every sin committed is in the first instance sin against God. God is the highest authority, and every sin is a form of rebellion against his authority. Therefore sin that is done to a fellow human being (particularly against a believer) is also done to God. Paul has persecuted the believers, but when he was confronted by God, he was asked: 'Saul, Saul, why do you persecute Me?' (Ac 9:4; NIV). In David's confession of sin against Bathsheba and Uriah, the same principle surfaced: 'Against you, you only, have I sinned and done what is evil' (Ps 51:4; NIV). Even sin that has been committed against oneself is therefore a sin against God. We are God's property, and what we have done against his property, has been done against him: 'You are not your own; you were bought at a price' (1 Cor 6:20; NIV). In Ezekiel 18:4 we read: 'For every living soul belongs to $\mathrm{Me}$, the father as well as the son - both alike belongs to $\mathrm{Me}^{\prime}(\mathrm{NIV})$. It goes without saying that only he, against whom man has sinned, is able to grant one forgiveness for one's sins.

Repentance is not possible without confession. Confession

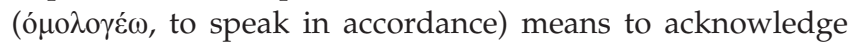

one's sin, by speaking in accordance with God (Ridderbos 1973:262). Therefore, it does not allow minimising sin. Adams (1973) clearly declares:

The New Testament word for 'confession' means to 'admit or acknowledge' or literally, 'to say the same thing'. Confession comes about when one views himself as God views him. Confession is saying the same thing that God says about one's sin. (p. 120)

Sin is primarily against God and was settled by Christ's death. It cannot be dealt with lightly. To minimise sin by calling it a weakness or a psychological problem is to underestimate what happened on the cross, and to show no understanding of the severity of the price paid. In confessing sin, it must be called what God calls it. This is not only the case in confessing sins, but also in forgiving others: 'If I minimize what others have done, I do not really forgive them. This was God's pattern with us. In order to forgive us he first had to hold us accountable for our actions' (Koessler 1999:176). Bonhoeffer (1964) writes:

... the confession of guilt is the re-attainment of the form of Jesus Christ who bore the sin of the world. For indeed the free confession of guilt is not something which can be done or left undone at will. It is the emergence of the form of Jesus Christ in the church. Either the church must willingly undergo this transformation, or else she must cease to be the Church of Christ. If anyone stifles or corrupts the Church's confession of guilt, his guilt towards Christ is beyond hope. (p. 116)

In dealing with sin and guilt, it should always be seen in the light of Christ's unconceivable suffering in this regard.

In the Old Testament repentance is usually expressed by the Hebrew word nacham. It is a word that could also be translated with penitence or remorse and is used in connection with both God (Gn 6:6) and man (Job 42:6). In the New Testament repentance is also used in connection with having remorse or sorrow (2 Cor 7:10), but the word most often used for repentance is $\mu \varepsilon \tau$ óvot $\alpha$, that could be literarily translated with 'to change one's thought or mind' as suggested in 2 Timothy 2:25. The New Testament concept of repentance goes deeper than 'feeling bad' or 'having sorrow', it also includes change. This is confirmed by Spring (1981):

There is no genuine repentance where there is no forsaking of sin. Still to go on in sin, to practice iniquity with greediness, with constancy, and with perseverance, is incompatible with the nature of that sorrow which is unto salvation. (p. 30)

\section{When repentance and confession is not evoked}

The willingness to offer forgiveness often leads to disappointment, especially God's willingness to offer forgiveness to mankind. The result is no reconciliation with God and eventually his rejection and condemnation over the sinner. Redemption and forgiveness of sin are inseparable: 'For He has rescued us from the dominion of darkness and brought us into the kingdom of the Son He loves, in whom we have redemption, the forgiveness of $\sin ^{\prime}$ (Col 1:13-14; NIV). 
In God's expectation of man to be willing to offer forgiveness to one another, man also experiences disappointment in this regard. If repentance and confession do not follow, forgiveness of sin from a Christocentric perspective does not allow the believer to grant the offender forgiveness in Christ's name. The unconditional willingness to offer forgiveness should not be confused with the conditional forgiveness or absolution of sin.

The principle is: without confession and remorse, no absolution can be given in the Name of Christ, otherwise one is not in line with God. It is important to understand something of God's righteousness in this regard. God hates sin, and will never overlook it. Sin has cost the life of his Son, Jesus Christ! Man needs to experience through the work of the Holy Spirit something of the misery of what happened on the cross, and not become so easily at ease with sin. A person who has sinned is not helped by words like 'Don't worry, it is not that bad.' In the light of Golgotha sin is always bad!

The offender is also not helped by a remark like 'I forgive and absolve you even if you have not shown any remorse' as implied by Meiring (2009:161-164). In fact, by doing that, a very negative message is communicated, namely that sin is not that bad, repentance is not needed - you are merely forgiven! This is an attitude that blasphemes against God's righteousness, and an injustice that cries out against the misery of the cross. By forgiving sins unconditionally, is to transgress against the enormous price paid by Christ in this regard. A cheap cover-up of sin does not help a person on the road of deliverance. In fact, by doing that, sin is ascertained even deeper in one's life. The biblical way of deliverance is not to be compromised; repentance and confession are always assumed.

Confession and remorse could of course also be expressed and communicated without words. This we see in Peter's behavior when Christ appeared to the disciples after his resurrection. Peter was so embarrassed and regretful of what he has done by denying Christ that, whilst fishing, he wrapped his garment around him and jumped into the water when the Lord appeared to him (Jn 21:7). Christ accepted this act as confession and remorse as illustrated by his questions concerning Peter's love for him (Jn 21:15-17; NIV). One should not insist on only a verbal confession and remorse; it can also be expressed by a person's deeds and attitude. If a person has sinned and shows remorse, regardless in what manner, the bestowal of forgiveness is expected.

An important question to be asked is: How should a person being dealt with who has sinned against his neighbour without confession or any signs of remorse? The Bible gives us guidelines in this regard. The following principles are important:

Firstly, one should be willing to offer forgiveness with the hope that it will provoke repentance and remorse. This hope is also seen in the waiting father as told in the parable of the prodigal son (Lk 15:11-32; cf. Thielicke 1959:30). The willingness to offer forgiveness is always unconditional as revealed in Christ's death for sinners.

Secondly, one should be aware not to accommodate bitterness or hatred against that person. In Romans 12:17 and 19 it is written:

Do not repay anyone evil for evil ... do not take revenge, my friends, but leave room for God's wrath, for it is written: 'It is mine to avenge; I will repay,' says the Lord. (NIV)

Bitterness and hatred harboured in one's heart lead to various forms of sicknesses. In this regard MacNutt (1979:154) writes: 'I have found it often helpful - sometimes essential - to consider a prayer for repentance or a prayer for inner healing first before praying for physical healing.' Bitterness and hatred boil down to, as someone said, drinking poison to kill your enemy! One only harms oneself.

Thirdly, one should distance oneself from the offender's sin committed against him. That is done by giving the person over to God. This act is a form of a willingness to offer forgiveness because the offender is given to him who has already offered forgiveness in Christ. It is a trust in God who knows the offender and will take revenge or deal with the case in his way. To do that is an act of faith in God's righteousness whereby one is freed (not necessarily the offender) from the effect of that person's sin against him. The liability of the offender's sin is now transferred from oneself to God with the knowledge that no one will merely escape from sin committed against man or God.

Paul has been in a similar situation. Alexander has sinned against him and never shown any remorse. Paul did not absolve his sins but wrote in 2 Timothy 4:14: 'Alexander the metalworker did me a great deal of harm. The Lord will repay him for what he has done' (NIV). It is not a case of Paul absolving or setting Alexander free of what he has done. He has rather distanced himself from Alexander by giving him to the Lord. It is God's responsibility to deal with Alexander, he will revenge. By doing that, Paul has freed himself from any negative hold Alexander might have on his emotions or his relationship with Christ.

The principle is: if one is assaulted, high jacked, robbed, humiliated, or being sinned against in whatever manner conceivable and no remorse is shown - one should distance oneself from it by giving it to God. No one should be deprived from joy and peace in Christ. God is righteous and he will revenge. Having this attitude will lead to peace. Christians should be aware not to become the yielded victim of other people's sins as revealed in their acts or words, but should live day by day depending on God who is always righteousness in all his actions. 


\section{Conclusion}

It has become clear that true forgiveness relates to what Christ has done for mankind in this regard. An acceptance of the centrality of Christ in understanding forgiveness both as an act of God and man, indeed leads to a powerful and creative enactment in destroying sin and its fruit in our relationship with God and our fellow human beings. Nowhere is God's unconditional love more clearly expressed towards our brokenness and sin as in Christ's practical theodicy revealed in forgiveness.

\section{Acknowledgements Competing interests}

The author declares that he has no financial or personal relationships which may have inappropriately influenced him in writing this article.

\section{References}

Adams, J.E., 1973, Competent to counsel, Presbyterian \& Reformed Publishing, Nutley.

Augsburger, D.W., 1995, 'Forgiveness', in D. Adkinson \& D. Field (eds.), New dictionary of Christian ethics and pastoral theology, pp. 389-390, InterVarsity, Leicester.

Barth, K., 1966, Dogmatics in outline, transl. G. Thompson, SCM, London.

Bash, A., 2007, Forgiveness and Christian ethics, Cambridge University Press, New York.

Bonhoeffer, D., 1964, Ethics, transl. N.H. Smith, SCM, London.

Brillenburg Wurth, G., 1957, Het Christelijk leven, Kok, Kampen.

Brunner, E., 1964, The Christian doctrine of creation and redemption, transl. O. Wyon, Lutterworth, London.

Cantalamessa, R., 2003, Come, Creator Spirit: Meditations on the Veni Creator, transl. D. Barrett \& M. Barrett, Protea Book House, Pretoria.

Collins, G.R., 1995, Family shock, Tyndale House, Wheaton.
Crabb, L., 1991, Men and women, Zondervan, Grand Rapids.

Duffield, G.P. \& Van Cleave, N.M., 1983, Foundations of Pentecostal theology, LIFE Bible College, Los Angeles.

Eichrodt, W., 1967, Theology of the Old Testament, vol. II, transl. J.A. Baker, SCM, London.

Fiddes, P.S., 2010, 'Salvation', in J. Webster, K. Tanner \& I. Torrance (eds.), The Oxford handbook of systematic theology, pp. 176-196, Lightning Source, Milton Keynes.

Foster, R., 1995, Seeking the kingdom, Hodder \& Stoughton, London.

Geisler, N.L., 2010, Christian ethics, 2nd edn., Baker, Grand Rapids.

Helberg, J.L., 1983, Verklaring en prediking van die Ou Testament, Potchefstroomse Teologiese Publikasies, Potchefstroom.

Koessler, J., 1999, God our Father, Moody Press, Chicago.

Küng, H., 1986, On being a Christian, transl. E. Quinn, William Collins, Glasgow.

Latourette, K.S., 1953, A history of Christianity, Harper \& Row, New York.

Lehmann, P., 1975, 'Forgiveness', in J. Macquarrie (ed.), A dictionary of Christian ethics, pp. 130-131, SCM, London.

Macaskill, A., 2005, 'Defining forgiveness: Christian clergy and general population perspectives', Journal of Personality 73(5), 1-14. PMID: 16138872, http://dx.doi. $\mathrm{org} / 10.1111 / \mathrm{j} .1467-6494.2005 .00348 . x$

MacNutt, F., 1979, Healing, Ave Maria Press, Notre Dame.

Macquarrie, J., 1992, Paths of spirituality, 2nd edn., SCM, London.

Meiring, P., 2009, 'Is vergifnis moontlik?', in L. van Niekerk (samest.), Die grootste geloofsurae, pp. 161-164, Carpe Diem Media, Vanderbijlpark.

Richardson, A., 1976, 'Forgiveness', in A. Richardson (ed.), A dictionary of Christian theology, p. 130, SCM, London.

Ridderbos, H., 1969, The coming of the kingdom, transl. H. de Jongste, Presbyterian \& Reformed Publishing, Philadelphia.

Ridderbos, H., 1973, Paulus, Kok, Kampen.

Spring, G., 1981, The distinguishing traits of Christian character, Presbyterian \& Reformed Publishing, Phillipsburg.

Talbott, T., 2008, 'Universalism', in J. Walls (ed.), The Oxford handbook of eschatology, pp. 446-461, Oxford University Press, New York.

Thielicke, H., 1959, The waiting Father, transl. J.W. Doberstein, Harper \& Row, New York.

Tournier, P., 1974, Guilt and grace, transl. W. Heathcote, Hodder \& Stoughton, London.

Vorster, J.M., 2004, Ethical perspectives on human rights, Potchefstroom Theological Publications, Potchefstroom.

Vos, C., 1988, Op soek na die sin van die lewe, Orion, Calvin \& Sales, Kaapstad.

Wright, H.W., 2009, A more excellent way to be in health, Whitaker House, New Kensington. 